$\mathrm{R} A D I O$ FATWA:

\title{
Islamic Tanya-Jawab Programmes on Radio Dakwah
}

\section{Sunarwoto ${ }^{1}$}

Tilburg University and NISIS Leiden, the Netherlands

\section{Abstract}

The present article is a study of radio fatwa in Indonesia with special reference to the Tanya-Jawab genres in radio dakwah. The concept of fatwa has changed over time. Such Islamic Tanya-Jawab programmes broadcast on radio dakwah are important to understand how fatwa is disseminated by means of media, since Islamic Tanya-Jawab programmes can be considered as part of fatwa. These programmes give not only information about Islam, but also become a forum in which interpretation of Islam takes place. This can be seen in the discussion on the Islamic ruling on eating "dog meat", in which interpretation of Islamic law is bighly contested.

[Artikel ini mendisukusikan radio fatwa di Indonesia, utamanya tentang program tanya-jawab yang disiarkan radio dakwah. Konsep fatwa terus berubah dan program tanya-jawab merupakan salah satu cara bagaimana fatwa disebarluaskan melalui berbagai media. Penulis berpendapat babwa program Tanya-Jawab dapat disebut sebagai salah satu bentuk fatwa. Ini karena program tersebut tidak saja mengetengabkan informasi mengenai Islam, namun juga interpretasi mengenai Islam. Pedebatan mengenai bukum memakan daging anjing merupakan salah satu contoh isu kontrovesial yang

${ }^{1}$ I would like thank Prof. Herman Beck for his insightful comments and Claudia Carvalho for editing my english. Both Prof. Herman Beck and Claudia Carvalho are from Tilburg University, the Netherlands. My thank goes also to Netherlands Interuniversity School for Islamic Studies (NISIS). 
akan dijelaskan melalui artikel ini.]

Keywords: Radio, fatwa, Tanya-Jawab

\section{A. Introduction}

The present article is a study of radio fatwa in Indonesia with special reference to the Tanya-Jawab genres in radio dakwah. ${ }^{2}$ There have been a great number of studies on fatwa in Indonesia written both by Indonesian and Western scholars. ${ }^{3}$ The state-of-the art of Indonesian Islam scholarship confirms Wael B. Hallaq's argument that 'there is massive evidence in our sources to indicate that fatwas played a considerable role in the growth and gradual change of Islamic substantive law.'4 And, at the same time, it has invalidated Emile Tyan's observation that the practice of fatwa will become obsolescent in line with the introduction of European law systems into the Muslim world. ${ }^{5}$ The participation of traditionalist Muslim organisations such as NU (Nahdlatul Ulama) in iftà activities $^{6}$ has also invalidated Deliar Noer who said, 'The traditionalists in Indonesia were following the established fatwa rather than the method of arriving

2 I shall use the term radio dakwah, instead of da'wah radio, exclusively to refer to the Indonesian context.

3 Among them are: M.B. Hooker, Indonesian Islam: Social Change through Contemporary Fatawa (Honolulu: University of Hawai'i Pres, 2003); Mohamad Atho Mudzhar, Fatwas of the Council of the Indonesian Ulama: A Study of Islamic Legal Thought 1975-1988, PhD Dissertation, University of California, Los Angeles, 1990. Nadirsyah Hosen, "Behind the Scenes: Fatwas of Majelis Ulama Indonesia (1975-1998)," Journal of Islamic Studies, 15:2 (2004), pp. 147-179; Piers Gillespie, "Current Issues in Indonesian Islam: Analysing the 2005 Council of Indonesian Ulama Fatwa No. 7 Opposing Pluralism, Liberalism and Secularism," Journal of Islamic Studies 18 (2) (2007), pp. 202-240; and others.

${ }^{4}$ Wael B. Hallaq, "From Fatwas to Furu': Growth and Change in Islamic Substantive Law," Islamic Law and Society Vo. 1, No. 1 (1994), pp. 30-31.

${ }^{5}$ E. Tyan, "Fatwa," Encyclopaedia of Islam, New Edition, Vol. 1 (Leiden: E.J. Brill, 1991), p. 866.

"On NU fatwa, see Nadirsyah Hosen, "NU and Collective Ijtihad," New Zealand Journal of Asian Studies, Vol. 6, No. 1 (June, 2004), pp. 5-26; Michael Laffan, "The Fatwa Debated? Shura in One Indonesian Context," Islamic Law and Society, Vol. 12, No. 1 (2005), pp. 93-121. 
at the fatwa. ${ }^{77}$ The traditionalists have formulated their own method.

Along these developments, studies on fatwa in Indonesia demonstrate that the concept of fatwa has been used loosely by many writers. So can be seen in the way by which they have chosen their sources. One among many examples is M.B. Hooker's Indonesian Islam: Social Change through Contemporary Fatawa (2003). The book provides us with various themes and employs a vast number of sources considered as fatwa. As shown in the appendix of this book, Hooker divides his sources into six in accordance with the number of the fatwa institutions under study, including Nahdlatul Ulama (NU), Muhammadiyah, Persatuan Islam (Persis), Majelis Ulama Indonesia (MUI), Ministry of Health (Bureaucratic Fatwa), and Badan Kerja Sama Pondok Pesantren (Cooperation Body of Pondok Pesantren). It is interesting that Hooker includes a subsection of the Ministry of Health, Council for the Evaluation of Health and Islamic Law, and identifies its Islamic legal consideration as 'bureaucratic fatawa'. By bureaucratic fatawa, he means 'a diverse set of publications put out by ministries having committees or councils for 'the evaluation of Islamic law' with reference to the activities of the ministry.' Specifically he analyses some fatwas concerning health issues produced by the Council for the Evaluation of Health and Islamic Law in the Indonesian Ministry of Health. The inclusion of the council is debatable. If the legal decision of this council can be called fatwa, then can the legal decision of the shari'ah advisory boards in non-governmental banks be called fatwa as well? Whatever the answer might be, this clearly demonstrates that what can be considered by a writer as a fatwa is very much dependent on what elements and perspectives he or she includes within and excludes from the rubric 'fatwa'. The degree of authority and strength of a fatwa is contingent in the sense that it is determined by a lot of factors such as the degree of acceptability of a fatwa by Muslims (to obey the fatwa) or the state (to implement the fatwa in state decisions). The criteria of the authority of a mufti or a fatwa institution are not only determined by religious or political factors, but also by a certain degree of consensus among its makers and that of the reception of Muslims as its askers. Thus,

${ }^{7}$ Deliar Noer, "The Development and Nature of Modernist Movement in Indonesia," in Ahmad Ibrahim, Sharon Shiddique, and Yasmin Hussain (eds.), Readings on Islam in Southeast Asia (Singapore: Institute of Southeast Asian Studies, 1985), p. 117. 
sociological factors are determinant as well in the acceptability of fatwa.

The role of modern media in disseminating fatwa is very important. Speaking on radio mufti in Yemen, ${ }^{8}$ Brinkley Messick starts with his critique of Western biases as reflected in Daniel Lerner's The Passing of Traditional Society which views the mass media, especially radio, as an 'advancing secular trend'. 'By dealing with the issuance of fatwa through radio, Messick tries to bring a religious trend to the fore. However, Messick closes his article with a quite contradictory stance. Underlining the linguistic nature of broadcasting media, he makes a concluding remark as follows: 'the voice is no longer that of the mufti himself but that of a professional broadcaster. ${ }^{10}$ By saying so, in my opinion, Messick fails to prove his critique and even agrees with Lerner. The failure is caused by the fact that he does not take seriously the religious trend he promises in the beginning of his article. He does not clearly identify what the religious trend means in connection with radio fatwa and mufti, whether it is the content of radio broadcasting or it is the result of broadcasting activities. Implied in his concluding remark above is the result of broadcasting activities. But, the result is not necessarily that the Islamic sermon of the radio mufti is less or even not influential to listeners, since it depends much on their success in making what Hirschkind has termed 'ethical performance. ${ }^{11}$ More importantly, Messick does not deal with the socio-religious and political context in which radio fatwa is broadcast. As a consequence, he does not inform us about the endeavours of the radio mufti in mobilising and convincing his listeners about a certain interpretation of Islam he believes to be true. My focus in this article is

${ }^{8}$ Brinkley Messick, "Media Muftis: Radio Fatwas in Yemen," in Muhammad Khalid Masud, Brinkley Messick, David S. Powers (eds.), Islamic Legal Interpretation: Muftis and Their Fatwas (Cambridge: Harvard University Press, 1996), pp. 310-320.

${ }^{9}$ Daniel Lerner, The Passing of Traditional Society: Modernizing the Middle East (London: The Free Press of Glencoe, 1964), p. 56.

${ }_{10}$ Brinkley Messick, "Media Muftis,” p. 320.

${ }^{11}$ Charles Hirschkind employes the term 'ethical performance' to analyse the practice of listening to cassette-recorded sermons in Egypt. By this term, he means 'a proper sermon audition demands a particular affective-volitional responsiveness from the listener'. According to Hirschkind, the ethical performance is 'a condition for understanding sermonic speech, while simultaneously deepening an individual's capacity to hear in this manner.' Charles Hirschkind, “The Ethics of Listening: Cassette-Sermon Audition in Contemporary Egypt," American Ethnologist, Vol. 28, No. 3 (2001), p. 624. 
different from Messick's. While Messick is concerned with the muftis, I focus on the Islamic programmes called Tanya-Jawab broadcasted on radio.

This article will examine the role of radio dakwah in the development of ifta institutions. I shall focus on a religious question-answer (Tanya Jawab) programme called Jihad Pagi broadcast on Radio MTA FM Surakarta, Central Java. The radio station belongs to the Yayasan Majelis Tafsir Al-Qur'an (MTA), ${ }^{12}$ a Muslim organisation in Surakarta which has recently attracted Muslims to or from the city and throughout the country due to its success in taking advantage of modern technology in its dakwah activities. ${ }^{13}$ I shall delineate the socio-religious and political context of a Tanya-Jawab session. Taking the contemporary development of fatwa discourses into consideration, I shall also deal with the very nature of fatwa, specifically in relation to radio dakwah. I argue that radio dakwah is of significance to the current scholarship on fatwa in Indonesia.

The questions to be answered in the present article are: can (or cannot) Islamic Tanya-Jawab programmes conducted on radio dakwah be called fatwa? What role has radio dakwah played in contemporary ifta' activities? To answer these questions, the article is divided into four sections. Firstly, it will discuss Tanya-Jawab programmes and their relationship with the concept of fatwa as it is important, since the concept of fatwa has changed over time. That is not to say that there is no continuity in the history of fatwa giving (iftä). Although the concept of fatwa has undergone some change, it has its roots in conventional Islamic disciplines, especially fiqh (Islamic jurisprudence) and usul al-fiqh (principles of Islamic jurisprudence). Secondly, I shall describe radio dakwah, especially in Surakarta, and its specific genre of Islamic questionanswer (Tanya-Jawab) programme. Next, I shall make a case study of Jihad Pagi programme on MTA FM and its relevance for media fatwa discourses. Specifically, a debate on eating dog meat will be dealt thoroughly so being relevant, since, as will be discussed, it is a question with which the Yayasan MTA has often been confronted with. By doing so, I hope the article will show a particular socio-religious and political context of a fatwa. Finally, the last section will be the conclusion.

${ }^{12}$ MTA can be an abbreviation of Majelis Tafsir Al-Qur'an, the name of the foundation (yayasan) to which it is affiliated, but it can also be that of Menuju Tatanan Adi (Toward an Excellent [Islamic] Order), the slogan or motto of this radio station.

13 I will discuss further about this radio and the Majelis Tafsir Al-Qur'an later. 


\section{B. Islamic Tanya-Jawab Programmes: Radio Fatwa?}

In this article, I use the concept of fatwa to comprehend the TanyaJawab programme genre broadcast in radio dakwah. One might wonder if this genre can be categorised as a kind of fatwa, since the practitioners giving Islamic advices on various themes to listeners are to my knowledge, in the Indonesian context, not commonly considered 'mufti'. They are mostly ustadh (teacher), muballig (itinerant preacher), or da' $i$ (preacher). Some of them are even trained not in madrasah (Islamic school) or pesantren (traditional Islamic boarding school). Having this in mind, the question of the nature of ifta $\vec{a}$ within the Tanya-Jawab programme is understandable: can Tanya-Jawab programmes broadcasted on radio be considered as iftä? If the answer is positive, then what should be the basic assumptions? I argue that such programmes can be understood as fatwa or part of iftä. Several assumptions underlie this argument. First of all, the concept of fatwa itself has changed over time, irrespective of the fact that there is continuity in some aspects of fatwa.

Fatwa, which stems from the root ' $f-t-w$ or $f-t-y,{ }^{14}$ is often simply translated as 'formal legal opinion' or 'Islamic legal edict'. In Indonesian language, the term is used very loosely. In Kamus Besar Babasa Indonesia (Official Dictionary of Indonesian Language), fatwa means: 1) an answer (decision, opinion) given by a mufti concerning a particular problem; 2) admonition of a learned man (Ind. alim, Ar. 'alim); good lesson; advice (petuab). ${ }^{15}$ As a generic term, Muslim authors tend to define the concept of fatwa in its loose meaning which, more or less, refers to the forms of question and answer in Islamic legal matters. Al-Raghib al-Asfahani (d. 402) defines fatwa and futya as 'the answer to the difficult legal questions (al-jawāb 'an-mā yushkil min'al-aḥkām). ${ }^{16}$ Al-Shātibi (d. 790/1388) puts forward that fatwa has the same meaning as iftä, an act of informing non-binding Islamic law (al-ikhbär bi hukem al-shar' là 'ala wajh al-ilāàm). ${ }^{17} \mathrm{In}$ defining fatwa, Mahmud Shaltut (d. 1963), a modern Egyptian mufti and

${ }^{14}$ See al-Tahir Ahmad al-Zawi, Al-Qämus al-Muhit, vol. 3 (Cairo: Dar al-Fikr, n.d.), p. 447.

15 Kamus Besar Bahasa Indonesia, http:/ / bahasa.kemdiknas.go.id/kbbi/index.php.

16 Al-Raghib al-Asfahani, al-Mufradat fi Gharib al-Qur'ān (Beyrut: Dār al-Ma'rifah, n.d.), p. 373 .

${ }^{17}$ Abu Ishaq Ibrahim b. Musa al-Andalusi, Fatawā al-Imām al-Shatibi (Tunis: Matba'ah al-Kawākib, 1985), p. 68. 
former rector of Al-Azhar University, refers to related Qur'anic verses in which there are two kinds of answer, some not preceded by questions and the others preceded by questions. According to Shaltut, the term fatwa applies to the second. Moreover, Shaltut distinguishes between alistifta' and al-su'al. The former needs a meticulous effort in creating an opinion (diqqah fi ibdä' al-ra'y), while the latter does not need it. ${ }^{18}$ Yusuf al-Qaradawi (b. 1926), another distinguished modern mufti, defines it as 'an explanation of religious law concerning a certain case as a response to the question of askers ...' (bayān al-hukm al-shar ' i fi qadiyyah mina'-qadàyà jawäban 'an su'äl säilin....). ${ }^{19}$ Except Shaltut, our sources cited here define the fatwa within Islamic legal matters.

Nevertheless, fatwa literature does not limit its scope to legal matters. It can also concern Islamic doctrine, economics, ethics and politics. Such a broad scope of fatwa has its historical roots in early Islam and can be apparently seen in modern Islamic discourses. Summarizing the conceptual history of fatwa, Muhammad Khalid Masud puts forward three different concepts, including management of general information about Islam, providing consultation to courts of law, and interpretation of law. The first concept has appeared in early Islamic history, when the fatwa referred to 'a question-and-answer process of communicating information about Islam' and its subject was Islam in general. With the establishment of Islamic schools of law and the compilation of legal literature, the term fatwa came to apply to legal matters uncovered in fiqh books. In line with the emergence of new Muslim states, fatwa had become more and more institutionalised, and muftis were incorporated into those states. Furthermore, Masud suggests that 'in order to appreciate current trends and developments, fatwa today should be seen as a function of management and the communication of information. ${ }^{20}$ Of course, Masud's suggestion is too broad to the extent that fatwa can cover everything informative about Islam. For that reason, it should be added

${ }^{18}$ Mahmud Shaltut, Al-Fatawā: Dirasah li-Mushkilat al-Muslim al-Ma'asir fi Hayatibi al-Yaumiyah, 18th ed. (Beyrut: Dar al-Shuruq, 2004),

19 Yusuf al-Qaradawi, Al-Fatwā baina al-Indibāt wa al-Tasayyub (Cairo: Dar alSahwah lil-Nashr wa-l-Tauzi', 1989), p. 11.

${ }^{20}$ Muhammad Khalid Masud, "Concepts of Fatwa," in John L. Esposito (ed.), Oxford Encyclopedia of the Modern Islamic World, Vol. 2 (New York: Oxford University Press, 1995), pp. 8-10. 
that the most distinctive feature of fatwa is the fact that it is issued upon request. Compared to khutbah (Islamic sermon), ${ }^{21}$ fatwa is more dialogical in the sense that there is a two-way communication between mufti and mustafti, irrespective of the fact that the nature of such communication is asymmetrical and hierarchical. Khutbah is oratorical rather than dialogical. It is given to the crowd in a form of one-way communication.

The next is concerned with the requirements of a would-be mufti and doing iftä. These have been formulated in Adab al-Mufti literature. Although this literature tends to emphasise the mature, timeless, and ideal character of mufti, it has undergone some significant changes. AlNawawi (d. 676/1277) mentions several conditions of a would-be mufti, who must be: an adult, Muslim, reliable, free of the causes of sin and defects of character, a jurist in identity, sound of mind, firm in thought, correct in behaviour and derivation and alert. ${ }^{22}$ Contemporary muftis like Yusuf al-Qaradawi set their own methods of issuing fatwa. Al-Qaradawi acknowledged that he formulated his own method of iftä after reading the methods of previous ulama in order to avoid blunders (al-mazaliq). ${ }^{23}$ The significant change was particularly in line with the absence of mujtahid mutlaq (a jurist who is qualified to do absolute independent Islamic legal reasoning). Hallaq has demonstrated that in Sunni legal theory, ijtihäd as one of the key prerequisites of issuing fatwa tended to lower gradually since al-Shafi'i (d. 820) until al-Ghazali (d. 1111). It did not mean that ifta $\bar{a}$ ' activities ceased to operate. Instead, changes took place in the way in

21 There have been a number of studies on khutbah, among which are: Johannes Pedersen, "The Criticism of the Islamic Preacher," Die Welt des Islams, Vol. 2 (19491950), pp. 215-223; Richard T. Antoun, Muslim Preacher in the Modern World: a Jordanian Case Study in Comparative Perspective (Princeton, New Jersey: Princeton University Press, 1989); Patrick D. Gaffney, The Prophet's Pulpit: Islamic Preaching in Contemporary Egypt (California: University of California Press, 1994); and Abdulkader Tayob, Islam in South Africa: Mosques, Imams, and Sermons (Gainesville: University of Florida Press, 1999).

${ }^{22}$ Ibn Sharaf al-Din al-Nawawi, Adäb al-Fatwa, wa-l-Muftï wa-l-Mustafẗi (Damascus: Dar al-Fikr, 1998), p. 19, as quoted in Masud, Messick, and Powers, "Muftis, Fatwas, and Islamic Legal Interpretation," in Muhammad Khalid Masud, Brinkley Messick, David S. Powers (eds.), Islamic Legal Interpretation: Muftis and Their Fatwas (Cambridge: Harvard University Press, 1996), p. 18.

${ }^{23}$ Yusuf al-Qaradawi, Al-Fatwa baina al-Indibāt wa al-Tasayyub, p. 107. 
which Muslim writers formulated requirements of fatwa issuance. ${ }^{24}$ These shifts in manuals of Adab al-Mufti, as Alexandre Caeiro has analysed, is concerned much with 'transformations in religious authority, subjectivity and agency.' These changes are also related to 'the shifting normative criteria that have defined the correct performance of a specific religious act .... ${ }^{25}$ In other words, the conditions and requirements are always subject to changes in accordance with the normative criteria used.

Looking at the Indonesian context, the practice of posing questions and giving answers on Islam not only refers to ift $\vec{a}$ ' and istiffta or fatwa as a generic term. Other terms such as keputusan (decision) and taushiyah (admonition or advice) are also used, even more frequently. Muhammadiyah, for example, called its official legal decisions Keputusan Majelis Tarjih and NU mentioned Keputusan Babtsul Masail respectively. The term taushiyah is also more commonly used, even by these two organisations and others. MUI (Majelis Ulama Indonesia, Indonesian Council of Ulama) and PKS (Partai Keadilan Sejahtera, Party of Justice and Prosperity) are two organisations which more extensively apply the term fatwa than others. Other similar terms might be also used in various publications, such as Tanya Jawab Agama (Religious Questions and Answers), Tanya Jawab Islam (Islamic Questions and Answers) and Anda Bertanya, Ustadh Menjawab (You ask, the Teacher answers). In view of such various terms used by MUI, Moch Nur Ichwan distinguishes between fatwa and taushiyah. ${ }^{26}$ According to him, there are four major differences. First is that fatwa is issued by a special commission (Komisi Fatwa dan Hukum, Commission for Fatwa and Islamic law), while taushiyah is not. Secondly, theoretically fatwa is much stronger than taushiyah. ${ }^{27}$ Thirdly, fatwa contains legal and dogmatic issues, while taushiyah covers social,

${ }^{24}$ Wael B. Hallaq, "Ifta', and Ijtihad in Sunni Legal Theory: A Development Account," in Masud, Messick \& Powers, Islamic Legal Interpretation, pp.33-43.

${ }^{25}$ Alexandre Caeiro, "The Shifting Moral Universes of the Islamic Tradition of Ifta: A Diachronic Study of Four Adab al-Fatwa Manuals," The Muslim World, Vol. 96, No. 4. (October 2006), pp. 661-685.

${ }^{26}$ Moch. Nur Ichwan, "Ulama, State and Politics: Majelis Ulama Indonesia after Suharto," Islamic Law and Society, Vol. 12, No. 1 (2005), pp. 51-52.

${ }^{27}$ Ichwan does not explain what he meant by the term 'stronger' in this article. He does not indicate whether a fatwa is stronger because of its binding effects on Muslims or because of its resulting decisions (either haram, prohibited, or halal, permissible, for instance). 
economic and political ones. And, the last is that the authority of fatwa is much greater than that of taushiyah. Such differentiation might be helpful in understanding MUI and its legal decisions. However, it might not be so when applied to other organisations, since most of them do not use the term fatwa specifically and exclusively. As I mentioned at the outset of this article, Hooker has selected his extensive sources on Indonesian fatwa, but only those sources of MUI are commonly called fatwa. Perhaps, the term 'fatwa-like', as used by Nico Kaptein, is more suitable to call such uncommonly-called fatwa. ${ }^{28}$ Regarding its authority, fatwa is not always stronger than the fatwa-like texts. In the case of Muhammadiyah, for instance, Keputusan issued by Majelis Tarjih is more binding than fatwa. ${ }^{29}$

Thirdly, with the absence of ideal requirements of a would-be muffi and doing ifta $\vec{a}$, new conditions have made it possible for Muslims to continue ifta' institutions. Partly, these conditions have been created by new forms of communication mediated by new communication technologies. Talking about the context of contemporary fatwa by Egyptian State-fatwa, Dar al-Iftä, Jakob Skovgaard-Petersen has given an interesting explanation about the invention of fatwa and mufti. According to him, this idea has been implied by the concept of fictitious fatwa once raised by Christiaan Snouck Hurgronje (d. 1936) ${ }^{30}$ and Ignaz Goldziher (d. 1921) who viewed that fatwa may be invented. Skovgaard-Petersen argues that the invention of fatwas, muftis, and mustaftis is more apparent with the advent of printed fatwas. By this idea, he refers to the fact that neither fatwa nor mufti can always be found easily if both are not vividly explained, especially when a fatwa is issued not in the form of face-to-face

${ }^{28}$ Nico Kaptein applies this term to those texts concerning admonitions, position statements, appeals, or thought contributions, which resemble fatwa. Nico Kaptein, "Introduction," Islamic Law and Society, Vol. 12, No. 1 (2005), p. 7.

29 Syamsul Anwar, "Fatwa, Purification and Dynamization: A Study of Tarjih in Muhammadiyah," Islamic Law and Society, Vol. 12, No. 1 (2005), p. 38. See also, Nico Kaptein, "Introduction," p. 7.

${ }^{30}$ C. Snouck Hurgronje wrote in German an article entitled, "Islam und Phonograph," Tijdschrift van het Bataviaasch Genootsehap, 42 (1900), pp. 393-427; and its short version in English appeared as "Islam and the Phonograph," The Muslem World, Vol. 5, No. 2 (1915), pp. 159-165. See also, J.J. Witkam, Fatwa's over de Fonografie van de Koran," ZemZem, No. 2 (2007), pp. 82-95, 139-140. 
communication. ${ }^{31}$ It seems to me that this idea can be deployed to the Tanya-Jawab programmes broadcast on radio dakwah, but with a different sense. By the invented fatwa and mufti, I mean those forms of question and answer communication which are not commonly considered as fatwa either by their audiences or by researchers. This can be applied to question and answer (Tanya-Jawab) programmes broadcasted on radio. In this respect, researchers have played a significant role in determining which Islamic question and answer communications can be ascribed to the term fatwa. What is called fatwa by researchers is not necessarily considered as fatwa by those practicing such kinds of question and answer communication. A mufti may also not identify himself/herself as mufti, but his/her audiences would call him so. The inventors might be either researchers or audiences.

By putting the radio-broadcasted Tanya-Jawab programmes within the concept of fatwa, I assume that such programmes could be considered, at least, as continuation of this long-established institution, if not fatwa itself. More importantly, Tanya-Jawab programmes demonstrate how Islamic doctrines are embedded in the daily lives of Muslims mediated by such modern technologies as radio. The use of modern technology in Indonesia to disseminate fatwa is not a novel thing, at least if we see the history of the early coming of the phonograph into this country as indicated above on Sayyid 'Uthman's fatwa. Mediated by such technologies, fatwa in particular and Islamic doctrines in general could reach wider audiences. Compared to other modern media such as television and the Internet, radio can approach much more audience. Its orality, aurality and inexpensiveness make it more easily accessible to a large mass of listeners. They can listen to radio everywhere while working in rice fields, driving car, and other daily activities. Moreover, different from print media and the Internet, people need no literacy to listen to the radio. ${ }^{32}$ Having this in mind, we can assume that fatwa or Tanya-Jawab programmes are more influential to Muslims.

31 Jakob Skovgaard-Petersen, Defining Islam for the Egyptian State: Muftis and Fatwas of the Dar al-Iftä' (Leiden, New York, Koln: Brill, 1997), p. 20.

32 See Edwin Jurriens, From Monologue to Dialogue Radio and Reform in Indonesia (Leiden: KITLV, 2009), p. 10. 


\section{Radio Dakwah and Its Tanya-Jawab Programmes}

Nowadays, the practice of posing questions and giving answers on Islamic religious matters (Tanya-Jawab Agama Islam) in Indonesia has been intensively conducted and published in various print and audio-visual and electronic media, such as Islamic magazines, television and radio stations, and the Internet. The term fatwa does not always appear clearly in those media. Other similar terms are mostly used in print media, such as Kolom Agama, Halaqah, and Kolom Tanya Jawab. As far as radio dakwah is concerned, the term fatwa is only used in Salafi radio dakwah stations as a specific religious broadcast programme. The programme contains a reproduction of Middle Eastern fatwas translated into Indonesian language. As an example, Radio Suara Qur'an in Sukoharjo, Central Java, regularly broadcasts a programme called Fatawa Mukbtarah (selected fatwas). The Fatawa Mukbtarah programme contains Indonesian-translated fatwas which are selected from various fatwa books or treatises written by Middle Eastern Salafi ulama such as Majmu'Fatāwā wa Maqälat Mutanawni'a by Bin Baz (d.1999) and Al-Masā'il al-Tlmiyyah wa al-Fatāwā al-Shar'iyyah by Al-Albani (d. 1999). To my knowledge, no Salafi activists ${ }^{33}$ in Indonesia is issuing fatwa. They rely completely on the existing Middle Eastern fatwas. This means that the ultimate authority of Salafi movements is

33 The term salafi deserves some clarification, since it refers to a broad concept of salafiyah (lit. ancestor) which means the followers of the ideas and practices of the past pious Muslim generations (al-salaf al-salih). Madawi el-Rasheed explains that the term salafi is 'an elastic identity,' since it can have several meanings. See Madawi el-Rasheed, Contesting the Saudi State Islamic Voices from a New Generation (Cambridge: Cambridge University Press, 2007), p. 3. Within this broad meaning can some Muslim organisations in Indonesia like NU (Nahdlatul Ulama) and Muhammadiyah be called or identify themselves as salafi or salaf. What I mean by 'salafi here is those ideologically linked to 'a contemporary whose worldview is based on the salaf-revivalist manhajj [method of thinking]'. Adis Dudireja has called this movement 'neo-traditional salafism' (NTS). They believe that 'the prophet's interpretation of the Qur'an as understood by the most eminent authorities belonging to the first three generations of Muslims (al-salaf al-salih) is normative, static and universalistic in nature (in terms of methodology/manhäj and its by-product, the creed/ 'aquda)'. See Adis Dudireja, "Constructing the Religious Self and the Other: Neo-traditional Salafi Manhaj," Islam and Christian-Muslim Relations, Vol. 21, No. 1 (2010), pp. 75-93. See also Fatawa al-Lajnah al-Da'imah li al-Bubuth al-Tlmiyah wa al-Iftä, vol. 2 (Riyad: Dar al-Mu'ayyad, 2003), pp.164-166. 
entirely on the hand of their mentors in the Middle East countries. ${ }^{34}$ However, some Salafi teachers have blogs providing a forum for Islamic question and answer. Other radio dakwah stations have a smorgasbord of question and answer programmes on Islam (Tanya-Jawab). ${ }^{35}$ What is interesting to note is that these programmes are highly interactive, where questioners or listeners and ustadh (pl. asätich, lit. male Islamic teachers) can communicate each other by telephone facilities or by sending SMS (short message service). Radio Suara Quran provides a special programme called SMS-Berjawab (Answering SMS), which replies to all not-yet answered questions. Most radio dakwah provide an On Air SMS service (layanan SMS on air). RDS (Radio Dakwah Syariah) FM, Solo, has a programme called taushiyah, broadcast off air every morning and on air every Friday morning.

It is worth making some comparisons with the Yemen context as Messick has described it. First of all, these radio dakwah are mostly affiliated to various Muslim organisations and groups. However, the religious affiliation of their listeners or questioners is not easily identifiable. What is clear is that they can be both members of those organisations or groups and unidentified common Muslim listeners. Those giving answers to listeners can be both the leaders of those organisations and their deputies, depending on what programmes they hold. Next, both women and men can participate in the Tanya-Jawab programme. Thus, radio dakwah in Indonesia have become a medium through which women can express their gender aspirations freely. They can pose direct questions about their women matters such as menstruation and religious devotions specific to Muslim women. There is no gender division, even on Salafi radio stations. ${ }^{36}$ This is different from the Yemen Islamic radio.

${ }^{34}$ As an example of Middle Eastern fatwa issued for Salafi movements in Indonesia, see Noorhaidi Hasan, "Between Transnational Interest and Domestic Politics: Understanding Middle Eastern Fatwas on Jihad in the Moluccas," Islamic Law and Society, Vol. 12, No. 1 (2005), pp. 73-92.

${ }^{35}$ It should be noted that Salafi radio dakwah stations have also this kind of Tanya Jawab programme, besides fatwa programmes.

${ }^{36}$ According to al-Lajnah al-Da'imah, the highest Salafi institution based in Saudi Arabia in charge of giving fatwa, the voice of women is part of aurat (something that must be concealed and not displayed publicly) for it can arouse the desire and temptation of men. Muhammad b. Abdul Aziz al-Musnad (comp.), Fatawa al-Mar'ah: Fatawa Regarding Women, English translation by Jamal al-Din M. al-Zaraboro (Riyad: 
As Messick has pointed out, although female listeners in Yemen can participate in posing questions to the radio mufti, al-Ghurbani, they can only ask through men or the wife of al-Ghurbani, and not directly. ${ }^{37}$ In the Yemen case, the radio mufti consulted his personal library before answering the questions posed to him. This seems different from the Jawab givers in radio dakwah. They answer the questions promptly, based on their memory of relevant Qur'anic verses or ha adiths or the opinions of previous ulama. Such a consultation might happen when they find it difficult to give direct answers to the questioners. In Radio MTA, for instance, the ustadhs often kept their exact answers for some time until they found their textual references.

Most, if not all, Tanya-Jawab sessions in radio dakwah are well preserved both in recordings and their websites and even in hard copies. Of course, the recordings of MTA's Tanya-Jawab provide more details concerning the content and process of giving jawabs (answers) than the websites and print publications, which contains only the general description of questions and textual sources of their answers. Radio MTA has very well-documented Tanya-Jawab, either in its website, recordings, or print publications. Its website provides textual sources in downloadable PDF files and .mp3 recordings. ${ }^{38}$ The printed textual bases are published yearly and arranged according to themes dealt with in each session of the Jihad Pagi. In this regard, compared to other radio dakwah, MTA is the most advanced in taking advantage of various modern media. In view of their being well-documented, radio dakwah gives more data than radio fatwa in Yemen. As Messick has told us, it is not possible for fatwa questioners to obtain the hard copy of those fatwas. ${ }^{39}$ An example of MTA FM radio with its Jihad Pagi or Ahad Pagi programme will depict how questions and answers (Tanya-Jawab) on Islamic issues are dealt with

Darussalam Publishers \& Distributors, 1996), pp. 338-339.

37 Messick, "Media Muftis," p. 316.

38 Since 2007 to 2011, they could have been downloaded free of charge. However, from 1 January 2012, they are not for free any longer. Subscription should be made and a certain amount of payment called infaq (donation) should be paid to be able to get access to them. According to its administrator, this was done after 'considering various needs and aspirations and advices from various sides.' See http://mtafm.com/ v1/?page_id=3637 (accessed 8 January 2012).

39 Messick, "Media Muftis," p. 318. 
and disseminated on air; and how significant those Tanya-Jawab are for understanding media fatwas.

\section{MTA and Radio MTA: A Profile}

Located in Pasar Kliwon area, Surakarta, MTA emerged first as a forum of Islamic lecture (pengajian) called Majelis Tafsir Al-Qur'an, led by Abdullah Thufail Saputra (d. 1992), a local merchant of Pakistani descent. He was a colleague of Abdullah Sungkar (d. 1999), the founder of Pesantren Al-Mukmin Ngruki, and Abdullah Marzuki (d. 1993), the founder of Pesantren Modern Assalam, both in Surakarta. At that time, these 'three Abdullahs', as a writer has called, were prominent leaders of the dakwah activists in the city. Together with Sungkar and Abu Bakar Baasyir, he established an Islam-based radio station called Radio Dakwah Islamiyah Surakarta (Surakarta Radio for Islamic Dakwah, RADIS) in 1970. The radio was banned to operate by the New Order regime, since it was regarded politically subversive. ${ }^{40}$

As a foundation (yayasan), MTA was established 19 September 1972 and gained legal recognition from the state in 1974. The main aim of this foundation is to summon Muslims back to the Qur'an with a specific emphasis on understanding, instilling and practicing of Qur'anic teachings. MTA was born not in the vacuum. Its establishment was inseparable from social conditions surrounding it. As stated in the website of MTA, in the 1960s and 1970s, Muslims were politically, economically, and culturally marginalised. Saputra viewed that this condition was caused by the fact that Muslims at that time lacked on their knowledge of the teachings of the Qur'an. Saputra believed that this could only be overcome by returning to the Qur'an. Being concerned about this deteriorating condition, Saputra established the foundation of Majelis Tafsir Al-Qur'an in 1972.

After the demise of Saputra in 1992, the leadership of MTA was handed down to Drs. Ahmad Sukino. ${ }^{41}$ It is interesting that, according

${ }^{40}$ On these three figures and their dakwah activities, see Muhammad Wildan, Radical Islamism in Solo: A Quest of Muslim's Identity in a Town of Central Java Indonesia, PhD Dissertation, Institute of Islamic World and Civilization, Universiti Kebangsaan Malaysia, Bangi, 2009, chapter 3.

41 Ahmad Sukino was born in Gawok, Sukoharjo, in 1948. He graduated from Tarbiyah faculty, Islamic Institute of Muhammadiyah (IAIM) which later was 
to Wildan, MTA holds the imamate system of leadership, which means that the post will be chaired by the appointed leader until the end of his life. ${ }^{42}$ This also explains his sole authority within the organisation, which impacts on all decisions made by this organisation. This sole authority is particularly decisive in a version of Islamic interpretation this organisation should take. As for Radio MTA, the decision of suitable Islamic programmes must be approved by Ahmad Sukino. As an example, in the early times of broadcasting, MTA played salawat (praying and praising the prophet) music as common among NU members. Knowing this, Sukino asked the crew of Radio MTA to stop playing salawat songs for it was not in accordance with the right teaching of Islam. ${ }^{43}$ That is also the case of the Jihad Pagi session in general, in which the leader plays its sole authority in giving jawabs.

Under the leadership of this latter, MTA has been developing significantly. ${ }^{44}$ This foundation organised various activities ranging from Islamic gatherings, formal and non-formal education, economic enterprises, health care, publishing (books and magazines), communication and information (radio station, TV station, and the website). In 2007, MTA has some 25 branches in the provincial level and more than 128 branches in the district level. The number of its members reached some 100,000 people from throughout the country. ${ }^{45}$ Until 2008, this foundation has run 134 schools in Java and elsewhere. ${ }^{46}$ Its public relations officer estimates that currently MTA has had more than 200 branches and representatives. ${ }^{47}$ This includes representatives abroad such as in Korea, Japan, and China.

The transfer of leadership seemed to have effects on the ideological development of MTA which became more textualist than ever, in

transformed into Muhammadiyah University of Surakarta (UMS).

${ }^{42}$ Muhammad Wildan, Radical Islamism in Solo, p. 87.

43 Recorded CD, Pengajian Ahad Pagi, Edisi 165 tentang Musik dan Nyanyian (2008).

${ }^{44}$ Syaifudin Zuhri, "Majlis Tafsir al-Qur'an and its Struggle for Islamic Reformism" in Kees van Dijk and Jajat Burhanuddin (eds.), Islam in Indonesia: Contrasting Images and Interpretations (Amsterdam: Amsterdam University Press, forthcoming 2013)

45 Muhammad Wildan, Radical Islamism in Solo, p. 88.

46 See Ricklefs, in Greg Feally \& Sally White (eds.), Expressing Islam: Religious Life and Politics in Indonesia (Singapore: Institute of Southeast Asian Studies, 2008), p. 125.

47 Communication with Sutikno, a public relations staff of MTA via Yahoo Messenger (YM), 1 December 2010. 
the sense that it tries to understand Islam only in accordance with its primary sources, the Qur'an and the sunnab (the Muhammadan exemplary practices) without much reference to other Islamic sources. During the era of Saputra, it seemed that MTA was very much influenced by modernist Muslim exegetes such as Muhammad 'Abduh (d. 1905) and Rashid Rida (d. 1935). Later on, in the present era of Ahmad Sukino its strong hold of the Qur'an and the sunnab has led to rarely or even never referring to other Islamic sources such as figh (Islamic law) or sirah (history of the prophet). ${ }^{48}$ In one session of Jihad Pagi, Ahmad Sukino once said (in Javanese), Nek Quran-mu karo Quran-ku padha, mesti unine padha (if your Qur'an and my Qur'an are the same, the wording must be the same). ${ }^{49}$ By this statement, he assummed that not only is the Qur'anic wording of various Qur'anic mushaf (Qur'anic book) the same but also the meaning and purport of the Qur'an is (or must be) precisely the same. Such a statement reflects its ideology of bringing Muslims back to the genuine teachings of the Qur'an. In this regard, MTA can be considered as a modernist movement in the sense that it has no ties with any madhhab (Islamic school of law). At the same time, it is puritan, since it attempts at purification of Islam from ingenuine and un-Islamic elements. ${ }^{50}$

As a puritan movement, MTA is struggling against local customs added to and regarded as Islamic rituals and festivities. Such concepts as syirik (Ar. shirk), bid'ah, and (sometimes) khurafat are used to label such rituals and festivities. With this in mind, Muhammad Wildan identifies MTA with Muhammadiyah which since its early operation aims to eliminate those un-Islamic elements by the concept of TBC (Tachayul,

48 Elsewhere I have analysed this tendency in connection with Qur'anic interpretation. See my "Antara Tafsir dan Ideologi: Telaah Awal atas Tafsir Al-Qur'an MTA (Majelis Tafsir Al-Qur’an)," Refleksi, Vol. XII, No. 2 (Oktober 2011), pp. 118-130. I should add here that my observation on MTA is different from that of Syaifudin Zuhri, who said that Ahmad Sukino is merely an interpreter of Abdullah Thufail's religious thought and a commentator of questions raised by MTA's members. See Syaifudin Zuhri, "Gerakan Purifikasi di Jantung Jawa: Studi tentang Majlis Tafsir AlQur'an (MTA)," in Yudian Wahyudi (ed.), Gerakan Wababi di Indonesia: Dialog dan Kritik. (Yogyakarta: Pesantren Nawesea Press, 2009), pp. 281-316.

49 This excerpt is taken from recorded CD entitled, Pengajian Ahad Pagi, Edisi 165 tentang Musik dan Nyanyian (2008).

${ }^{50}$ This puritan category is used by Ricklefs, Syaifudin Zuhri, and Agiel Siradj. 
Bid'ah, dan Churafat). ${ }^{51}$ Nevertheless, such a concept is followed by many modernist groups other than Muhammadiyah, such as al-Irsyad and Persis (Persatuan Islam). In my opinion, MTA is much closer to Persis (Persatuan Islam) in terms of their respective strict interpretation of Islam.

MTA has no explicit ties with a certain political party. However, this does not necessarily mean that it has no political significance in the sense that it has much access and well-established contact with the state. This has become more apparent since Presiden Susilo Bambang Yudhoyono (SBY) inaugurated the opening of MTA's new building located in the front of Mangkunegaran Palace on 8 March 2009. During SBY's visit, Ahmad Sukino lamented the difficulty of gaining the broadcast permit for Radio and TV MTA. In response to this lamentation, SBY said, 'I don't like to promise, for that reason I ask the minister of communication and information to help to realise [the legal radio and television station] in accordance with the existing law. Dakwah is important, the dakwah is the true teaching of Islam. ${ }^{52}$ The result of this closeness to the state was that, the broadcast permit was given to Radio MTA FM and its new radio station centre PERSADA FM (in Sragen city) in September 2009. ${ }^{53}$ A number of the government officials, including some SBY's ministers, visited MTA, such as Siti Fadlilah Supari (Minister of Health), M.S. Ka'ban (Minister of Forestry), both ministers of SBY's first term cabinet, Nazaruddin Umar (the then Dirjen Bimbingan Masyarakat Islam of the Religious Affair Ministry and current Vice-minister of Religious Affairs).

In addition to the state, MTA has also made a close cooperation with other Muslim organisations, among the most important of which are MUI, at local and national level. At the local level, the chief of MUI Surakarta is the most often involved in MTA's important moments. At the national level, Drs. H Amidan, KH Cholil Ridwan, Muhyidin Junaidi, and Syafi'i Antonio are the most prominent figures of MUI who were often invited to give Islamic lectures in MTA or attended the opening of its new branches. For MTA, MUI is the organisation which has gave

51 See Muhammad Wildan, Radical Islamism in Solo, p. 87.

52 "Al-ustadz Keluhkan Sulitnya Memperoleh Ijin Radio dan TV di Hadapan Presiden," http://mtafm.com/v1/?p=999 (accessed 6 January 2012). Italic English words are original.

53 “Kabar Gembira Perizinan Radio MTAFM," http://mtafm.com/v1/?p=14. (accessed 6 January 2012). 
much support to its dakwah activities. ${ }^{54}$ In addition, it has a vigilante force often joined by a number of demonstrations organised by several Muslim organisations. ${ }^{55}$ It joined FUI (Forum Umat Islam, Forum of Muslims) in demanding the dissolution of Ahmadiyah in Indonesia. ${ }^{56}$ On 24 August 2007, MTA sent a delegation to Hizbut Tahrir Indonesia (HTI)'s conference. ${ }^{57}$ On 19 February 2010, it participated in a demonstration against the withdrawal of the Law No. 1/PNPS/1965 on the Prevention of Religious Defamation (Pencegahan Penyalahgunaan dan/atau Penodaan Agama).$^{58} \mathrm{~W}$ ith these participations in mind, MTA has played a significant role in contemporary Muslim movements in Indonesia.

In addition, as a newly go-public organisation, MTA has tried to build its religious identity acceptable to Muslims surrounding it. Compared to NU and Muhammadiyah, MTA is a minority group. As a minority, ${ }^{59}$ it seems to follow what is so called ghurabä (Ar., sing: gharib, meaning stranger) ideology. This ideology tries to emphasise that the genuine Islam is often considered strange just like when it came to the world at the first time. It is taken from an authentic hadith which says: 'Islam strarted as a stranger, and it will return as it started; so blessed are the ghuraba' (those strange people). ${ }^{60}$ This ideology is common not only among Salafi groups, ${ }^{61}$ but also among Muslim minority groups such as MTA. The followers of this ideology believe that their Islamic interpretation is authentic since it is based on the primary sources of

${ }^{54}$ This can be seen, for example, in a news report entitled "MUI Menyertai MTA dalam Mengembangkan Dakwah" (MUI Supports MTA in Developing Dakwah) at http://mtafm.com/v1/?p=2236 (accessed 7 January 2012).

55 Muhammad Wildan, Radical Islamism in Solo, p. 90.

56 See http://www.suara-islam.com/news/gerakan-islam/harakahkontemporer/3569-fui-umat-islam-menunggu-keppres-pembubaran-ahmadiyah

57 Ricklefs, "Religion, Politics and Social Dynamics in Java," p. 126.

${ }^{58}$ http://mta-online.com/v2/2010/02/20/42-organisasi-di-surakarta-tolakpencabutan-uu-anti-penodaan-agama/

${ }^{59}$ I use this minority category following a research report made by Badan Penelitian dan Pengembangan Provinsi Jawa Tengah (Body of Research and Development Central Java Province), Laporan Penelitian tentang Interaksi Sosial Kelompok Aliran Islam Minoritas dalam Masyarakat di Berbagai Daerah di Jawa Tengah, 2006.

${ }^{60}$ See, for instance, Abu al-Husain Muslim ibn al-Hajjaj al-Qushairi al-Naisburi, Șabih Muslim, Vol. 1 (Beirut: Dar al-Kutub al-'Ilmiyah, 1991), pp. 130-131.

${ }^{61}$ On the concept ghuraba' among Salafis, see the website of Bin Baz: http:// www.binbaz.org.sa/mat/4724 (accessed 6 January 2012). 
Islam, the Qur'an and the badith. They consider themselves strange because they hold the true Islam which is different from that hold by majority Muslims, which is deviated from the truth. The present hadith is also used by MTA to respond to difficulties by its members in a number of regions for their dakwah activities. As an example, in Jihad Pagi session on 1 August 2010, Ahmad Sukino explained about the challenges in the struggle for Islam based on the Qur'an and the sunnah. In the website of MTA, it is said that '... even some of our brothers [and sisters] who conducted religion according to the tuntunan (the correct guidance) will be marginalised, boycotted and even expelled by physical violences. ${ }^{62}$ Therefore, although MTA does not apply the term ghuraba', it tries to use the idea of 'strangeness' to construct its religious identity within the context of competition among the existing Muslim groups.

Let us move on to Radio MTA. Currently, MTA has become increasingly public owing to its success in developing its radio network, called Radio MTA FM 107.9 MHz. It was initiated in 2005 and it started its broadcast in the beginning of 2007 as a community radio (radio komunitas). It is stated that the format of broadcast programmes in this radio is imbued with Islamic values in order to attract listeners who are eager to know Islamic shari'ab based on the Qur'an and the sunnab. ${ }^{63}$ To reach a wider audience, MTA FM provides listeners with easy access through various modern communication technologies. Since 2010, MTA's programmes can be accessed through satellite (Satelit Palapa), which makes listeners from outside Java Island such as Irian Jaya or Papua, Sumatra, Kalimantan, and Sulawesi, easier to listen to and participate. Some of them have been attracted to come to the Central Building of MTA in Surakarta to participate directly in Jihad Pagi programme. The broadcast programmes of MTA can be accessed through its live streaming online at its website: http://mtafm.com/ which is also accessible to Blackberry users. Thanks to its cooperation with one of the biggest telephone companies in Indonesia, Telkomsel, listeners can easily enjoy MTA's programmes via their mobile phones.

MTA FM has various broadcasting programmes, ranging from

62 "Ujian Umat Terdahulu Jauh Lebih Berat Daripada Kita," http://mtafm. com/v1/?p=2337\#more-2337 (accessed 7 January 2012); and its recorded Jihad Pagi version, code number: 100801_jp.

${ }^{63}$ http://mtafm.com/v1/?page_id=1140 (accessed 1 December 2011). 
Islamic sermons, Quranic reading, health consultation, agro-business, and economy, to music. Some $70 \%$ of them are categorised as dakwah programme, including Pengajian Ahad Pagi (Jihad Pagi), Fajar Hidayah (The Dawn of God's Guidance), Murattal Qur'an (Qur'anic Reading), Hikayah (Islamic theatrical story), Risalah Tafsir (Discourse on Qur'anic interpretation), Risalah Hadits (Discourse on Hadith), Ustadz Menjawab (The Teacher Answers), Tabsin Al-Qur'an (the Art of Reading the Qur'an), Hikmah (Wisdom), and Muhasabah (introspection). ${ }^{64}$ Relevant with the topic of this article are programmes which can be categorised under the genre of Islamic questions and answers (Tanya-Jawab Islam). In this respect, MTA FM has at least three programmes, namely Fajar Hidayah (The Dawn of God's Guidance), Ustadz Menjawab (The Teacher answers) and Jihad Pagi (Morning Jihad). Fajar Hidayah is broadcast every morning (the word 'fajar' itself means 'dawn' or 'early morning) at 05.00-06.00, featuring ustad₹s of MTA except Ustadz. Ahmad Sukina who regularly chairs the Jihad Pagi programme on Sunday morning. Various topics are dealt with on Fajar Hidayah, including Islamic doctrines, figh, and daily religious matters. On Sunday morning, Fajar Hidayah deals specifically with health issues. In this programme, listeners can raise their questions by phone, by sending SMS as well as by sending text messages through Yahoo Messenger (YM).${ }^{65}$ Ustadz, Menjawab is similar to Fajar Hidayah, but it is broadcast on every Thursday afternoon at 16.00-17.00.

\section{E. Jihad Pagi}

Jibad Pagi or Pengajian Ahad Pagi is a main Islamic gathering (pengajian) conducted by MTA (Majelis Tafsir al-Qur'an, Council of Qur'anic Interpretation) every Sunday morning. ${ }^{66}$ It has been established since the era of Abdullah Thufail. With the establishment of Radio MTA, Pengajian Ahad Pagi has been broadcast lively. The recorded version of Jihad Pagi is relayed three times every day, consisting of Jihad Pagi 1 (part

${ }^{64}$ Nur Ariyanto, Strategi Dakwah Majelis Tafsir Al-Qur'an (MTA) Melalui Radio MTA 107,9 FM Surakarta, BA thesis (Semarang: Fakultas Dakwah IAIN Walisongo Semarang, 2010), p. 97.

${ }^{65} \mathrm{http}: / /$ mtafm.com/v1/?page_id=40. (accessed 1 December 2011). I myself often participated by sending SMS as well as text messages via Yahoo Messenger (YM). 2011).

${ }^{66} \mathrm{http}: / / \mathrm{mtafm} . c 0 m / \mathrm{v} 1 /$ ?page_id=43\#comment-1473. (accessed 1 December 
1) at 06:00-07:00, Jihad Pagi 2 (part 2) at 14:00-15:30 and Jihad Pagi Hari Ini at 19:00-21:30 (part 1 and 2 relayed back together in one session). The term jibad (lit. struggle) used for this gathering session is interesting, since it has become more widely used by Western media, especially after the 9/11 tragedy in the US in 2001, in its negative sense as a kind of violence and terrorism. The situation was worsened by the fact that after the 9/11 tragedy, bombings happened in some parts of Indonesia such as in Bali and Jakarta. MTA views that Islam does not acknowledge any of terrorism, since it is in contradiction to Islamic teachings ${ }^{67} \mathrm{Ahmad}$ Sukino, the leader of MTA, said, 'it is only those of anti-Islam who regard Islam terrorism. It is those ignorant who consider Islam identifiable with terrorism. It is only those losing sights who identify Islam with terrorism. ${ }^{68}$ Explaining how the MTA has collected donation, it is stated in its website that there are two kinds of jihad, including jibad bi al-anfus (physical Islamic struggle) and jihad bi al-amwal (Islamic struggle through wealth). It can be understood from this view that for MTA jihad is more than a physical struggle. Furthermore, as Marle Ricklefs has noted, MTA views that terrorism in the name of Islam has discredited purification movements. Rather than demanding the formal implementation of shari'ah, MTA prefers to emphasise the importance of grassroot's understanding of the shari'a itself. It believes that by giving Muslims a true understanding of Islamic shari ${ }^{6}$ ah, its implementation is automatically completed. ${ }^{69}$

The Jihad Pagi is relayed on air as well as off air through the MTA FM radio station from 07:30 to 10:30 o'clock. Some 5000-6000 Muslims from various regions within and outside Surakarta such as Surabaya, Bandung and Jakarta come every Sunday morning to this gathering. Before the Jihad Pagi session starts, a brochure containing Qur'anic verses and hadith (the prophet's saying) related to relevant themes dealt with is distributed. Those present in this gathering can raise their questions both in written forms and directly to the ustad\%. By and large, questions raised are based on this brochure for asking clarification, but other questions might also appear naturally. Those who are not present can ask friends to offer their questions in this session. In addition, two MTA radio reporters

${ }^{67}$ Yayasan MTA, “Terorisme dalam Pandangan Islam,” Brosur No. 1472/1512/ IA, Sunday, 23 August 2009/02 Ramadlan 1430, p. 6.

${ }^{68}$ See http://mtafm.com/v1/?p=1320 (accessed 01 January 2012).

${ }^{69}$ M.C. Ricklefs, "Religion, Politics and Social Dynamics in Java," p. 125. 
(male and female) make some interview with several male and female audiences while waiting for the coming of the ustadz (Ar. ustadh). In this interview, questions which frequently pop up are how they know MTA, what they think about MTA and their feeling after knowing MTA. Most of them knew MTA through listening to the MTA radio programmes, in addition to their neighbours. They often expressed their fortune and happiness to have known MTA as through it they understood that 'true' Islam was based on the Qur'an and the sunnah.

In what follows I shall illustrate how a question and answer session occurred in the Jihad Pagi. An example concerning the Islamic ruling on eating dog eat will be dealt with in depth. As this session cannot be separated from what so-called Brosur, I shall also touch upon this material and then examine the method of legal reasoning that MTA follows. A comparison will be made between MTA and Persis (Persatuan Islam, United Islam) in order to get precedence from the past.

\section{F. Question on Eating Dog Meat: An Example}

I shall start with the context in which the session under discussion occurred. Why is the question on the Islamic ruling on eating dog meat crucial? And, what is the social context of this question? For most Indonesian practicing Muslims, eating dog is religiously unlawful (haram). Since they are mostly the followers of the Shafi'i law school, touching wet dog skin and its saliva is even forbidden. If they do, they must clean parts of their bodies contacting with a wet dog seven times, one of them sprinkled with pure soil. With regard to eating dog meat, except the Maliki, three madhābib (sing. madhbab) or Islamic schools of law agree on its being unlawful (haram). The Maliki scholars are divided into two groups: one consider makrub (reprehensible) and the other baram. ${ }^{70} \mathrm{~A}$ further explanation on these differing opinions is beyond the scope of this article. What I want to highlight is that this is the theological reason why this dog meat eating has become a heated issue among society. Apart from this doctrinal reason, no less important is the fact that presently in Surakarta (and Yogyakarta as well), many (street) food stalls sell various kinds of food made of dog meat such as sate gukguk, sengsu (abbr. oseng-

${ }^{70}$ See 'Abd al-Rahman al-Jaziri, Al-Fiqh 'ala al-Madhabib al-Arba'ah, vol. 2 (Beyrut: Dar al-Kutub al-'Ilmiyah, 2003), p. 7. 
oseng asu), sate jamu and rica-rica jamu. According to one source, some 1.500 dogs are slaughtered every day for supplying those stalls. ${ }^{71}$ This means that dog meat has a quite high economic value for some people in both regions (Surakarta and Yogyakarta). With the burgeoning of such stalls and the high demand of dog meat, Dinas Pertanian (Dispertan, Agriculture Office) of Solo was worried about the possible spread of rabies virus among people. The office admitted that this spread was difficult to control..$^{72}$

The names of dog meat-made food are interesting by themselves, since they reflect local culture and norms in Javanese context. The word 'guk-guk' refers to the barking sound of dogs. Sengsu is the abbreviation of oseng-oseng asu, which means 'sautéed dog meat'. The word 'asu' here means dog, which can be insulting if it is used to name a person. Thus, this abbreviation is used to avoid sarcasm and impoliteness especially according to Javanese norms and culture. The word 'jamu' in such terms as sate jamu and rica-rica jamu is another important point to highlight, since it relates to the third aspect of this issue, namely myths of eating $\operatorname{dog}$ flesh. The Javanese word 'jamu' means 'traditional medicine'. Some people believe that eating dog meat can increase stamina or sexuality. As reported by a local media in Surakarta, this belief attracted many people to consume dog flesh. ${ }^{73}$

It is within this context that a question about the Islamic legal status of eating dog meat popped up in the Jihad Pagi session is significant to discuss. MTA itself was often charged of legalising dog flesh eating. The

${ }^{71}$ See http://www.solopos.com/2011/solo/minim-pengawasan-1-500-anekor-anjing-\%E2\%80\%9Cdibunuh $\%$ E2\%80\%9D-untuk-sate-guk-guk-119666; www. jagoanberita.com, "Minim Pengawasan, 1.500-an Ekor Anjing "Dibunuh" untuk Sate Guk-guk," http://jagoanberita.com/tampilkan/minim-pengawasan-1-500-anekor-anjing- $\%$ E2\%80\%9Cdibunuh $\% \mathrm{E} 2 \% 80 \% 9 \mathrm{D}$-untuk-sate-guk-guk. (accessed 5 December 2011).

72 "Fenomena Penjualan Makanan Olahan Daging Anjing di Solo," Harian Joglosemar, 25 July 2011; "Pemkot Sulit Kendalikan Peredaran Daging Anjing," Harian Joglosemar, 15 October 2011. Also “Warung Daging Anjing Merebak, Dispertan Resah," at http:/ / www.kabar7.com/index.php?option $=$ com_content\&view $=$ article\&id $=318: \mathrm{w}$ arung-daging-anjing-merebakdispertan-resah\&catid=5:daerah\&Itemid=17 (accessed 5 December 2011).

73 "Satu Guk-guk Diburu karena Mitos Jamu," http://harianjoglosemar.com/ berita/sate-guk-guk-diburu-karena-mitos-jamu-49701.html (accessed 8 January 2012). 
peak of this charge involved one of the officers at the Ministry of Religious Affairs who supposedly accused in March 2011 that MTA considered dog meat halal. But, why was this charge raised toward MTA? As far as I am concerned, there are no written documents as well as recordings that can clearly tell us about this. In my opinion, it is not enough for MTA to state that it does not consider dog meat halal. It must also condemn it as haram. This is because MTA offers an open interpretation to its audience by not condemning dog meat. This is exacerbated by the fact that the Jihad Pagi programme is broadcast on radio, which means that audiences are free to make their own interpretation. Their heterogeneous Islamic background and knowledge play significant roles in their reception.

In response to the above question, in the Jihad Pagi session the leader of MTA, Ahmad Sukino, said that this charge was insulting to his organisation. ${ }^{74} \mathrm{~A}$ question was posed concerning the Islamic ruling (bukm) on dog meat, which reads as follows: ${ }^{75}$

Question: is dog flesh really halal or haram? Please explain [to me/us] a clearly as possible. Because in my kampong a kiyai, who memorised the Qur'an, made a comment before his yasinan congregation that: 'my ears become itchy when listening to this radio (station). It is said that dog flesh is halal, whereas even its saliva is najis (religiously impure), even it is said [that] its flesh is halal.' This comment came to my ears and spontaneously I said: 'Hopefully, his ears would be really itchy forever. Did [because of] my prayer lead me to be sinful?

This question reveals some important points. One concerns the terms kiyai (Javanese traditional Muslim title) and yasinan (reading the Qur'anic chapter Yasin). Brought together, both terms might refer to a specific Muslim identity called Nahdliyyin which means followers of Nahdlatul Ulama (NU) organisation, even though some followers of Muhammadiyah conduct yasinan and call some of their leaders kiyai. MTA's criticism of popular traditions such as those maintained in the NU tradition seems frequently to cause a tension between followers of these two organisations, MTA and NU. On April 2011, a polemic appeared in a daily newspaper, Jawa Pos, in Surabaya, East Java, involving the head of Tanfidziyah council of NU and the general secretary of MTA. The

74 “Pejabat Depag Pusat Dituduh Lecehkan MTA". See http://suaramerdeka. com/v1/index.php/read/news/2010/03/21/49808 (accessed 5 December 2011).

75 Recorded Jihad Pagi, 21 August 2011. 
later considered the former to have made 'fitnab' (false accusation) for considering MTA to have banned yasinan and tablilan. The polemic was triggered by Siraj's article entitled 'Menyikapi Kegarangan Puritanisme' (Facing the Aggressive Puritan Movement) which in early paragraphs describes a tension among followers of both organisations in Purworejo, Central Java. ${ }^{76}$

As the answer of the above question was addressed in a highly informal form, it is difficult to present it completely here. The only way is to excerpt some relevant ideas from it. At least, three main issues can be found in this session, including the charges or critiques raised to MTA, the attraction of people to MTA and the responses of MTA to the charges as to the ruling on dog meat. MTA regarded all criticism raised against it with regard to the lawfulness of eating dog meat as fitnah (seduction, false accusation, slander), dengki (envy, jealousy) and hawa nafsu (passion). Those charges are a fitnah because they are in contradiction to the fact that MTA never declares that eating dog meat is permissible. They are jealous of the fact that the sympathisers of MTA have become more and more increasing. They are attracted to attend Jihad Pagi, even from remote provinces. MTA regards those critiques as a kind of passion (hawa nafsu), by which it means the desire of those critics to discredit and undermine MTA in public. According to Ahmad Sukino, people' increasing attraction to MTA is inseparable from the fact that MTA provides them only with the Qur'an and the sunnah. He used the metaphor 'menu' to describe the content of Jihad Pagi, which provides the audience with the authentic and fresh menu 'the Qur'an and the sunnah. He said,

“... if you want to ngaji (J., meaning attending Islamic lesson), just come to [MTA building in] the front of Mangkunegaran [Royal Palace]. The building is beautiful, isn't it? It is [always] full of crowd ... The subjects of discussion all are explained by Brosur along with the Qur'anic and the sunnab texts plus a question-answer forum ..."

Furthermore, Ahmad Sukino tried to convince his audience that MTA does not declare dog meat as halal (lawful). In his answer to the question above, he repeated similar wordings several times, about seven times in this session. The terms 'tidak pernah' (never) and 'tidak akan

${ }^{76}$ Said Aqiel Siradj, "Menyikapi Kegarangan Puritanisme," Jawa Pos, 5 April 2011; and Yoyok Mugiyatno, "Beda Boleh, Putus Silaturahmi Jangan,” Jawa Pos, 14 April 2011. 
pernah' (will never) appeared frequently in order to counter those critics. Let us look at those seven wordings as follows.

1. 'Radio MTA will never explain [that] dog meat is halal ... you will never hear [that $]^{77}$

2. 'I declare: MTA never ... since its establishment, until ... insha Allah [God's willing] forever ... will never say, never consider dog [meat] bala! ${ }^{78}$

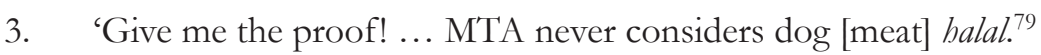

4. 'MTA here is to study, deliver [the message of] the Qur'an and the prophet sunnah ... [to humankind]. It is unlikely to declare something is halal, which is never mentioned in the Qur'an. ${ }^{80}$

5. 'Don't tell, "This is halal, this is haram, according to your own words without the authentic basis of the Qur'an. [If so], that means you lie., ${ }^{81}$

6. 'MTA will never consider dog [meat] halal and will never consider [it] halal. $^{82}$

7. 'Halal-haram is absolutely in the hand of Allah. ${ }^{83}$

As can be seen, with the exception of numbers 4 and 5 , these quotations are concerned directly with the question of eating dog meat. Numbers 4 and 5 explain about the textual doctrinal basis on which MTA based its opinions. They clearly demonstrate that MTA is not in position to justify those who consider dog meat as halal, and it based its opinion on the Qur'an. Those repeated wordings seem to prove the MTA's consistent stance toward the debate on the Islamic ruling on eating

77 Radio MTA tidak akan menerangkan daging anjing itu halal ... kamu tidak akan pernah dengar.'

78 'Saya katakan: MTA tidak pernah ... sejak. MTA berdiri, .. insyaallah sampai besuk ... tidak pernah akan mengatakan, tidak akan pernah menghalalkan anjing. Nggak pernah.'

79 'Buktikan! ... Nggak pernah MTA menghalalkan anjing.'

${ }_{80}$ 'MTA itu di sini mempelajari, menyampaikan al-Quran dan sunnab Nabi ... Nggak mungkin akan menghalalkan sesuatu, mengharamkan sesuatu, yang tidak disebut dalam al-Quran.'

81 Jangan kamu mengatakan 'ini halal, ini haram, menurut ucapanmu sendiri tanpa dasar kebenaran dari al-Quran. Itu berarti kamu mengadakan kebohongan.'

${ }^{82}$ 'MTA tidak akan pernah menghalalkan anjing dan tidak akan menghalalkan ...'

83 'Halal-haram itu mutlak milik. Allah ...' 
dog meat. It is absolutely clear that MTA never, and will never, declares $\operatorname{dog}$ meat as halal. However, there is one interesting point to note. That is the fact that MTA never gives its opinion on the unlawful status of eating dog meat. This is also true if we look at the related Brosur, which is another important source of MTA, besides the recorded material one. Regarding the textual basis, the Qur'an seems to be the only source to decide both the permissibility and interdiction of eating dog meat in particular and food and animals in general. In those seven quotations above, the sunnah appeared once, but it is not specifically to speak about food and animals. However, it is the sunnah as one of the main subjects dealt with in MTA lessons. It seems to me, the absence of the haram condemnation is the fundamental reason why MTA is easily charged of considering dog meat halal. By making no declaration on the haram-ness of dog meat, MTA leaves people to interpret and draw conclusions on their own ways. They, for instance, can interpret by applying the principle mafhum al-mukhälafah (understanding a text through its opposite meaning) as in the Islamic jurisprudence. ${ }^{84}$ Thus, it that it is permissible to eat dog, since the Qur'an neither mentions nor interdicts it. In view of the fact that Jihad Pagi programme is broadcast on radio station and that the Brosur gives simply quite short explanation, audience or listeners have more freedom of making further interpretation or even misinterpretation.

It is worth asking if the principle of mafhum al-mukhälafah is used by MTA? In one of its Jihad Pagi session on 24 May 2009, Ahmad Sukino was illuminating the concept of bid'ah (innovation in religious matters) by reference to the badith saying that the prophet bequeathed only two things with which Muslims will be guaranteed save in the hereafter, mainly the Qur'an and the sunnah. Sukino viewed that the mafhüm al-mukhälafah of this hadith is that any newly invented devotion to Allah, which are not mentioned in these two primary sources of Islam, should be considered bid'ah.

\section{G. Method of Reasoning: Islamic Principles on Food}

To understand the above-mentioned Jawab, we have to examine the method of reasoning used by MTA. This method can be inferred from

${ }^{84}$ On mafbum al-mukhälafah, see for instance, Abd al-Wabhab Khallaf, Ilm Usul al-Fiqh (Maktabah al-Da'wah al-Islamiyyah Shabab al-Azhar, 2002), pp. 153-161. 
the Islamic principles underlying its decision on the Islamic ruling on food. Therefore, I will elaborate these in two steps: explaining Islamic principles on food held by MTA and sources of the Jawab. During 2011, MTA has issued eleven numbers of Brosur under the title 'Halal Haram dalam Islam' (Halal and Haram in Islam) ${ }^{85}$ Nine numbers consist of eighteen points concerning Islamic principles on food, animals, differing opinions on food and animals. Two numbers (10 and 11), which I will not discuss in this article, deal specifically with animal hunting. These principles are mentioned in numbers 1-5 of the Brosur. I would restructure those principles into ten as follows.

The first principle is that with regard to food, MTA follows a legal maxim that the principle in all things is permissibility (al-asl fi al-ashya $\vec{a}$ al-ibähah). ${ }^{86}$ Therefore, everything whose halal and haram status is not explained in the principle (ass) should be considered balal. ${ }^{87}$ This principle applies not only to things but also to acts, including 'adat (local custom) and mu'amalah (social transaction). ${ }^{88}$ In the case of 'ibadah (worship), MTA holds that there are two principles to follow, including: worshipping only One God; and, this could be accomplished only by following what has been prescribed by the shari' ${ }^{6} .^{89}$ The source of 'adat and mu'amalab is not shari' (the maker of shari' $a$, God), but human. Both are permissible except what is clearly forbidden by the shar' $i^{90}$ The worship must be conducted in accordance with the shari' a prescribed by God. By contrast, custom must not be forbidden, except with the prescription of God..$^{11}$ Secondly, for MTA, the decision on halal and haram is only in the hands of God. Those

85 They are: Brosur No. 1563/1603/IF (17 July 2011/15 Sya'ban 1432); Brosur No. 1564/1604/IF (31 July 2011/29 Sya'ban 1432); Brosur No. 1565/1605/IF (7 August 2011/7 Ramadan 1605); Brosur No. 1566/1606/IF (14 August 2011/14 Ramadan 1432); Brosur No. 1567/1607/IF (21 August 2011/21 Ramadan 1432); Brosur No. 1568/1608/ IF (28 August 2011); Brosur No. 1569/1609/IF (4 Sept 2011/5 Syawwal 1432); Brosur No. 1570/1610/IF (11 Sept 2011/13 Syawwal 1432); Brosur No. 1571/1611/IF (25 Sept 2011/ 27 Syawwal 1432); Brosur No. 1572/1612/IF (2 Oct 2011/4 Dzulqo'dah 1432); and Brosur No. 1573/1613/IF (9 Oct 2011/11 Dzulqo'dah 1432).

${ }^{86}$ Brosur No. 1563/1603/IF, p. 1.

87 Brosur No. 1563/1603/IF, p. 2.

88 Brosur No. 1563/1603/IF, p. 4.

89 Brosur No. 1563/1603/IF, p. 4.

90 Brosur No. 1563/1603/IF, p. 5.

91 Brosur No. 1563/1603/IF, p. 6. 
who dare to decide halal and haram have transgressed God's limits and disobeyed God's right. ${ }^{92}$ Humans thus have no power to make a decision. What they can do is only to explain God's law. According to MTA, 'our task is merely to explain the hukm ruled by God on halal and haram. ${ }^{\prime 93}$

The third principle is that considering the halal as haram and the other way around is a serious sin. This opinion is based on Qur'anic verses, including Q. 6: 116; 5: 103-104; 6: 143-144; 7: 32-33; and 5: 8788. These verses are divided into Makkiyah (those sent down in Mecca), including Q. 6: 116 and 143-144; 7: 32-33, and Madaniyah (those sent down in Medina), including Q. 5: 87-88, 103-104. Those Makkiyah verses were revealed to strengthen 'aqidah (Islamic doctrines) and tawhid (monotheistic principles). In view of the purposes of the revelation of those verses, MTA maintains that halal and haram are not a branch but a principle in Islam. It goes on to say that when some Muslims in Medina became excessive in considering the halal as haram, 'Allah sent verses which brought them back to the right path. ${ }^{94}$ Fourthly, to regard the halal as haram will cause some difficulty; ${ }^{95}$ this is because God's decision on halal and haram bears maslahah (goodness, interest) for humankind. Here it refers to Qur'anic stories concerning the prohibition ordained by God on Jews concerning eating some food and animals (Q. 6: 146 \& 4: 161). With the coming of Muhammad as the last prophet, that prohibition was abolished. This was and is, for MTA, a kind of God's mercy (rahmat) for Humans. ${ }^{96}$ Fifthly, whatever causes the haram is haram. ${ }^{97}$ Based on this principle, not only are the practitioners of haram acts sinful but also those who help to do them. For instance, as in Islam khamr is haram, those who produce, bring (to others), being given, and sell it are sinful altogether. ${ }^{98}$

The sixth principle is that any stratagem (bilah) concerning the haram (i.e., to make it halal) is haram. ${ }^{99} \mathrm{By}$ the hilah, MTA means 'naming something forbidden (baram) by another name, and changing [its] form

\footnotetext{
92 Brosur No. 1563/1603/IF, p. 6.

93 Brosur No. 1563/1603/IF, p. 8.

${ }^{44}$ Brosur No. 1564/1604/IF, p. 5.

95 Brosur No. 1564/1604/IF, p. 6.

${ }_{96}$ Brosur No. 1564/1604/IF, pp. 7-8.

${ }^{97}$ Brosur No. 1565/1605/IF, p. 1.

98 Brosur No. 1565/1605/IF, p. 1.

99 Brosur No. 1565/1605/IF, p. p. 3.
} 
[into another], which is in its essence the same. ${ }^{100}$ In line with this principle, the seventh principle is that good intention does not excuse the haram. ${ }^{101}$ Haram is haram, for whatever good intention and purpose one might have. ${ }^{102} \mathrm{Next}$, the eighth principle is avoiding the subbat (vague status of being halaland haram) for fear of being engaged with the haram. ${ }^{103}$ The ninth, principle is that haram applies for all people, ${ }^{104}$ since God's shari' ${ }^{\prime}$ h transcends kinship, nations, races, and groups. The tenth principle is that the emergence excuses the forbidden. ${ }^{105}$ This is translated from the Islamic legal maxim, al-dharurat tubih al-mahdhurat. The principle has its textual bases in the Qur'an (for instance Q. 2: 173; 6: 119) which put a restriction on the scope of mabdhurat (the prohibited). According to MTA, all ulamas agreed that what is so called darurat (emergency) in the case of food ruling is famine. Q. 2: 173 makes an exception by the phrase 'ghaira baghin wa la 'adin' (without wilful disobedience, nor transgressing due limits). The Brosur reads, 'not to make any justification to serve his desire' (tidak mencari-cari alasan untuk memenubi keinginannya). ${ }^{106}$

From the principles mentioned above, it is clear that MTA puts the authority of God over that of others. It tends to emphasise the universalities of Islamic law. As a consequence, it avoids particularities by bringing them back to the main source. This becomes much clearer when it faces the diversity of opinions of ulama on the Islamic ruling on food. MTA acknowledges that there are different opinions among ulama concerning the Islamic ruling on food. It divides them into two groups. The first group considers that there are only four kinds of food declared haram by Allah, namely: dead meat, blood, flesh of swine and that which is slaughtered in the name of other than Allah (sacrificed not for Allah). In this respect, MTA argues that the prohibition on food in hadith is only makrub. ${ }^{107}$ By the term makruh, it means that if one eats it,

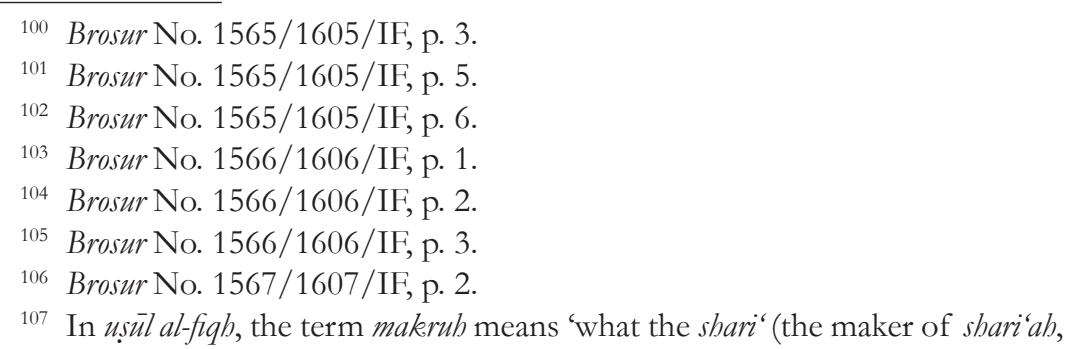
God) has order from mukallaf (the adult) not to do it indeterminately.' See Abd alWahhab Khallaf, IIm Usül al-Fiqh, p. 114. MTA's definition of this term is similar to that 
one is not sinful, and if he or she avoids it, he or she will deserve Allah's reward. By contrast, the second group maintains that except for four mentioned in the Qur'an, what is forbidden in the hadith is forbidden to eat as well. ${ }^{108}$ Towards this difference, MTA seems to take an ambiguous position, since it chooses one of these opinions only implicitly. What is clear is that MTA bases its arguments on Q. 6: 145; 16: 115; 2: 173; and 5: 3. For MTA, of these four verses, Q. 5: 3 is the most detailed, since it covers another three verses. It says further as follows:

'Animals 'which hath been killed by strangling, or by a violent blow, or by a headlong fall, or by being gored to death; that which hath been (partly) eaten by a wild animal' can be categorised into 'dead meat' (maitah), and 'that which is sacrificed on stone (altars)' is similar to those slaughtered in the name of other than Allah.' Both are the same. Shortly, globally ('ijmali) [kinds of] food which are forbidden [to eat] consists only of four, and if explained in detail [that] would be ten, as stated in al-Ma'idah [5]: $3 .{ }^{109}$

It is interesting that in some ways MTA mentioned dissent opinions of ulama, but at the same time it avoided identifying them by name or group. Rather than giving some names of ulama or Islamic schools of law, it tended to simply make generalisation, putting them into one group or another. Consequently, we do not know, for instance, those ulama MTA refers to who advocate the principle that haram food and animals mentioned in the badith. This might be intended to provide information as concise and clear as possible, since the Brosur is distributed to common Muslims, not to specialists. None the less, this might also be because of its non-madhhab orientation, bringing all the differences back to the main sources of Islam, the Qur'an and the hadith. The position of hadith itself in the case of dog meat is not quite clear, whether it is an explanation (tabyin or tafsi) of the Qur'an as suggested by fuqabä' (Muslim jurists) as well as Muslim interpreters (mufassirü). What is clear is that MTA uses no hadith concerning the haram-ness of dog meat. Instead, it upholds its

of Yusuf al-Qaradawi who says that the makruh is 'what one deserves God's reward for leaving it, and there is no punishment for doing it.' But, what al-Qaradawi means here is makrūh tanzīhi (religiously lawful), not makrüh tabrimi (strictly abominable). See Yusuf al-Qaradawi, Fiqh al-Awlawiyat: Dirasah Jadidah fi Daw' al-Qur'an wa al-Sunnah (Cairo: Maktabah Wahbah, 1996), p. 206.

108 Brosur No. 1568/1608/IF, pp. 1 \& 8.

109 Brosur No. 1567/1607/IF, p. 5. 
opinion by citing other hadiths, among them is the hadith narrated by Abu Darda', 'Whatever Allah has permitted in his book is halal and whatever He has forbidden is haram and whatever he is silent about it is a forgiveness ('afw). So please take from Allah his forgiveness, since Allah never forgets anything.' Other similar hadiths by other narrators are also quoted, which MTA views as dha'if (weak or unsound ḥadith). ${ }^{110}$ According to Sukino, if there are dha'if hadiths with the same meaning as sabih hadith, the former serve to corroborate the latter. ${ }^{111}$ However, MTA does not employ this principle to those hadiths explaining in detail the kinds of the unlawful animals not yet mentioned in the Qur'an.

MTA's opinion on eating dog meat is quite similar to that of SoalDjawab, the key book of Persatuan Islam (Persis, United Islam) in terms of its arguments as well as textual bases. Although their conclusion is the same, they differ in making a conclusive wording. Soal-Djawab was cowritten by Ahmad Hassan, Moh. Ma'sum and Mahmud Aziz. Examining the legal thought of Ahmad Hassan, one of the important writers of SoalDjawab, Akhmad Minhaji mentions Hassan's fatwa on dog meat. Minhaji views that this fatwa was influenced by Imam Malik, the founder of the Maliki School of law. Unfortunately, he neither indicates his source nor elaborates further this topic. ${ }^{112}$ It might be because he could not find the very source he used or he considers it a taboo for discussion. Reading two volumes of Soal-Djawab, one might not be able or difficult to find a specific theme on the Islamic ruling on eating dog flesh. What one will find in there is the Islamic ruling on touching a dog and its saliva or selling a dog. Included in the fatwa on selling a dog and taking its payment is the explanation that dog meat is allowed to consume. However, this is not a fatwa given by Ahmad Hassan but by Mohammad Ma'sum, one of the co-writers of Soal-Djawab. This can be seen in the end of the fatwa where Md. Mm is registered. Md. Mm stands for Mohammad Ma'sum.

The opinion held by Ma'sum is influenced not by Imam Maliki, but, as he himself acknowledged, by Imam Abu Hanifah. The question to

110 Brosur No. 1563/1603/IF, p. 2.

111 Recorded Jihad Pagi, 17 July 2011.

112 Minhaji said 'his fatwa that eating dogs is permissible is a clear example of his indebtedness to the ideas of Malik.' See, Akhmad Minhaji, "Ahmad Hassan and Islamic Legal Reform in Indonesia (1887 1958)", PbD Dissertation, McGill University (1997), p. 325. 
which Ma'shum responds is as follows: 'What is the ruling on selling a dog and taking its payment?' In response to this, Ma'sum said, 'Concerning this, ulama have different opinions which are divided into three; and here will be explained one by one, in order for you, readers, to be able to consider.' Then a lengthy exposition is given to those three opinions together with their textual bases. The first is that dog is haram either for sale or for taking its payment. This opinion is held by most fuqahä' (abl al-fiqh) and abl al-hadith (hadith scholars). Similar to the first opinion, the second is that it is haram to sell a dog and take its payment except a hunt $\operatorname{dog}$ which is allowed to sell and take its payment. This is the opinion of Imam 'Ata' and Imam al-Nakha'i. And, the third one is the opinion that everything forbidden by God is forbidden to sell and take its payment. The third opinion is more general, since it includes everything forbidden by God, and not only dog.

Ma'sum then moves to the discussion about food. He said, 'according to the right information, the food outlawed by Allah is what has been outlawed in his book, the Qur'an.' he cites a hadith narrated by al-Bazzar on the authority of Abu Darda' who said: 'Whatever Allah has permitted in his book is halal and whatever He has forbidden is haram and whatever he is silent about it is a forgiveness ('afw). So please take from Allah his forgiveness, since Allah never forgets anything.' To explain the terms halal and haram in this hadith, Ma'sum then quotes two Quranic verses, including Q. 2: 173; and 6: 145. Inferring from these Qur'anic verses, he said, 'therefore except these four things outlawed by Allah, everything is halal. If anything more [than these] is [considered] haram, [that] would be explained by Allah. Shortly speaking, with the explanation of those two Qur'anic verses, it can be inferred that the animal called anjiang is allowed for sale, since Allah does not interdict eating its meat.' He examined all hadith texts supporting the first and second opinions by analysing the reliability of their narrators (rawis). I will not describe them here in detail. What is important to present is that Ma'sum comes to the following conclusion:

Hadiths which prohibit taking benefit from the price of dog mentioned in Nos. 3, 4, 5, [and] 15 is not acceptable, even if their sanad (chains of transmission) are authentic, because they oppose Quranic verses, 
and hadith mentioned in No. 11 which explains that if Allah declares something unlawful, He declares them their price, whereas [eating the meat of] dog is not forbidden by Allah. By this explanation, one can understand the weakness of the first opinion and the second one; one can also understand the authenticity of the opinion that dog is allowed to sell, and it is permissible (bala) to take its benefit. This is [the opinion of] the school of Imam Abu Hanifah. ${ }^{113}$

It can clearly be seen from the above description there are some similarities and differences between MTA and the Soal-Djawab. Both share in making Qur'anic pre-texts as the sole foundation for deciding the ruling on eating dog meat. The legal reasoning of both MTA and Soal-Djawab is the same. With this in mind, the conclusion should also be the same. However, the context in which the answer of MTA is given has forced it to take a different way. The Soal-Djawab blatantly declares that eating dog meat is lawful, whereas MTA simply states that it will never considers dog meat lawful. More importantly, in this position MTA never condemns eating dog meat. On the one hand, MTA wants to be in tune with its commitment to following the textual meaning of the Qur'an as precisely as possible. But, on the other hand, social norms regarding the Islamic ruling on dog meat propel it to avoid commenting on its haramness. Compared to Soal-Djawab, MTA seems to be reluctant to channel its conclusion to the opinion of previous ulama by not mentioning their groups, school of law or madhähib (sing. madhhab).

\section{H. Conclusion}

In contemporary Indonesia iftä activities have never ceased to operate. Muslim organisations such as Muhammadiyah, NU and MUI have continued to produce fatwa in response to a great array of problems facing Muslims in the country. Modern communication technologies have become important media for the dissemination of fatwa. Outside the 'official' ifta' institutions, there are questions and answers on Islamic matters presented in and through various media, printed as well as electronic. They have taken different forms such as Kolom Agama, SoalJawab, Tanya-Jawab Islam, Ustadz Menjawab, and SMS-Berjawab. I have dealt

113 A. Hassan, et. al, Soal-Djawab tentang Berbagai Masalah Agama, Vol. 2 (Bandung: CV. Diponegoro, 1969), p. 726. 
with these kinds of question and answer on Islam with special attention to Tanya-Jawab programmes in radio dakwah. I have also made a case study of the Jibad Pagi programme broadcast on Radio MTA FM and a discussion about the Islamic ruling on food.

The concept of fatwa has changed over time. Such Islamic TanyaJawab programmes broadcast on radio dakwah are important to understand how fatwa is disseminated by means of media. Islamic Tanya-Jawab programmes can be considered as part of fatwa. These programmes give not only information about Islam, but also become a forum in which interpretation of Islam takes place. This can be seen in the discussion on the Islamic ruling on eating dog meat above, in which interpretation of Islamic law is highly contested. On the one hand, the leader of MTA has to provide the askers not only with answers but also legal reasonings on which his answers base. On the other hand, he has to respond to critiques or charges raised to his organisation. Within this context, he seemed to face a dilemma and was forced to take a conclusion which actually opposed his method of reasoning. The theme of the discussion itself is not new, but the question about it is raised within a real context of Muslims' contemporary daily life of the asker. 


\section{BIBLIOGRAPHY}

Al-Andalūsì, Abū Ishāà Ibrahim b. Musa, Fatāwà al-Imām al-Shātibī, Tunis: Matba'ah al-Kawakib, 1985.

Al-Asfahānì, al-Raghỉb, Al-Mufradāt fi Ghärib al-Qur'àn, Beyrut: Dar alMa'rifah, n.d.

Al-Naisabūrî, Abū al-Husain Muslim ibn al-Hajjaj al-Qushairî, al-Jāmi al-Ṣahīh, vol. 1, Beirut: Dār al-Kutub al-'Ilmiyah, 1991.

Al-Nawāwi, Ibn Sharaf al-Din, Adab al-Fatwa, wa al-Mufti wa al-Mustafti, Damascus: Dar al-Fikr, 1998.

Al-Qaradawi, Yusuf, al-Fatwa baina al-Indibat wa'l-Tasayyub, Cairo: Dar alSahwah li'l-Nashr wa'l-Tauzi', 1989.

----, Fiqh al-Awlawiyàt: Diräsah Jadidah fi D a aw' al-Qur'an wa'l-Sunnah, Cairo: Maktabah Wahbah, 1996.

Al-Zawi, al-Tahir Ahmad, al-Qämus al-Mubit, vol. 3, Cairo: Dar al-Fikr, n.d. Antoun, Richard T., Muslim Preacher in the Modern World: a Jordanian Case Study in Comparative Perspective, Princeton, New Jersey: Princeton University Press, 1989.

Anwar, Syamsul, "Fatwa, Purification and Dynamization: A Study of Tarjih in Muhammadiyah," Islamic Law and Society, Vol. 12, No. 1, 2005.

Ariyanto, Nur, "Strategi Dakwah Majelis Tafsir Al-Qur'an (MTA) Melalui Radio MTA 107,9 FM Surakarta", BA thesis, Semarang: Fakultas Dakwah IAIN Walisongo Semarang, 2010, p. 97.

Brosur No. 1563/1603/IF.

Brosur No. 1564/1604/IF.

Brosur No. 1566/1606/IF.

Brosur No. 1567/1607/IF.

Brosur No. 1568/1608/IF, pp. 1 \& 8.

Caeiro, Alexandre, "The Shifting Moral Universes of the Islamic Tradition of Ifta: A Diachronic Study of Four Adab al-Fatwa Manuals," The Muslim World, Vol. 96, No. 4, October 2006, pp. 661-685.

Dudireja, Adis, "Constructing the Religious Self and the Other: Neo- 
traditional Salafi Manhaj," Islam and Christian-Muslim Relations, Vol. 21, No. 1, 2010, pp. 75-93.

El-Rasheed, Madawi, Contesting the Saudi State Islamic Voices from a New Generation, Cambridge: Cambridge University Press, 2007.

Gaffney, Patrick D., The Prophet's Pulpit: Islamic Preaching in Contemporary Egypt, California: University of California Press, 1994.

Gillespie Piers, "Current Issues in Indonesian Islam: Analysing the 2005 Council of Indonesian Ulama Fatwa No. 7 Opposing Pluralism, Liberalism and Secularism," Journal of Islamic Studies 18, 2, 2007, pp. 202-240.

Hallaq, Wael B., "From Fatwas to Furu': Growth and Change in Islamic Substantive Law," Islamic Law and Society, Vol. 1, No. 1, 1994, pp. 30-31.

Hasan, Noorhaidi, "Between Transnational Interest and Domestic Politics: Understanding Middle Eastern Fatwas on Jihad in the Moluccas," Islamic Law and Society, Vol. 12, No. 1, 2005, pp. 73-92.

Hassan, A., et al, Soal-Djawab tentang Berbagai Masalah Agama, Vol. 2, Bandung: CV. Diponegoro, 1969.

Hirschkind, Charles, "The Ethics of Listening: Cassette-Sermon Audition in Contemporary Egypt," American Ethnologist, Vol. 28, No. 3, 2001.

Hooker, M.B., Indonesian Islam: Social Change through Contemporary Fatawa, Honolulu: University of Hawai Press, 2003.

Hosen, Nadirsyah, "Behind the Scenes: Fatwas of Majelis Ulama Indonesia (1975-1998)," Journal of Islamic Studies, 15:2, 2004, pp. 147-179.

----, "NU and Collective Ijtihad," New Zealand Journal of Asian Studies, Vol. 6, No. 1, June 2004, pp. 5-26.

Hurgronje, C. Snouck, "Islam und Phonograph," Tijdschrift van het Bataviaasch Genootsehap, 42, 1900, pp. 393-427

Ichwan, Moch. Nur, "Ulama', State and Politics: Majelis Ulama Indonesia after Suharto," Islamic Law and Society, Vol. 12, No. 1, 2005.

Jurriens, Edwin, From Monologue to Dialogue Radio and Reform in Indonesia, Leiden: KITLV, 2009 
Kaptein, Nico, "Introduction," Islamic Law and Society, Vol. 12, No. 1, 2005, p. 7.

Laffan, Michael, "The Fatwa Debated? Shura in One Indonesian Context," Islamic Law and Society, Vol. 12, No. 1, 2005, pp. 93-121.

Lerner, Daniel, The Passing of Traditional Society: Modernizing the Middle East, London: The Free Press of Glencoe, 1964.

Masud, Muhammad Khalid, "Concepts of Fatwa", in John L. Esposito (ed.), Oxford Encyclopedia of the Modern Islamic World, Vol. 2, New York: Oxford University Press, 1995.

----, Brinkley Messick, David S. Powers (eds.), Islamic Legal Interpretation: Muftis and Their Fatwas, Cambridge: Harvard University Press, 1996.

Messick, Brinkley, "Media Muftis: Radio Fatwas in Yemen," in Muhammad Khalid Masud, Brinkley Messick, David S. Powers (eds.), Islamic Legal Interpretation: Muftis and Their Fatwas, Cambridge: Harvard University Press, 1996, pp. 310-320.

Minhaji, Akhmad, "Ahmad Hassan and Islamic Legal Reform in Indonesia (1887-1958)", PhD Dissertation, McGill University, 1997.

Mudzhar, Mohamad Atho, "Fatwas of the Council of the Indonesian Ulama: A Study of Islamic Legal Thought 1975-1988", PhD Dissertation, University of California, Los Angeles, 1990.

Noer, Deliar, "The Development and Nature of Modernist Movement in Indonesia," in Ahmad Ibrahim, Sharon Shiddique, and Yasmin Hussain (eds.), Readings on Islam in Southeast Asia, Singapore: Institute of Southeast Asian Studies, 1985.

Pedersen, Johannes, “The Criticism of the Islamic Preacher," Die Welt des Islams, Vol. 2, 1949-1950, pp. 215-223

Ricklefs, in Greg Feally \& Sally White (eds.), Expressing Islam: Religious Life and Politics in Indonesia, Singapore: Institute of Southeast Asian Studies, 2008).

Shaltut, Mahmud, al-Fatāwā: Dirāsah li-Mushkilāt al-Muslim al-Ma'așir fi Hayatibi al-Yaumiyah, 18th ed., Beyrut: Dar al-Shuruq, 2004.

Skovgaard-Petersen, Jakob, Defining Islam for the Egyptian State: Muftis and Fatwas of the Dar al-Iftà, Leiden, New York, Koln: Brill, 1997.

Tayob, Abdulkader, Islam in South Africa: Mosques, Imams, and Sermons, 
Gainesville: University of Florida Press, 1999.

Tyan, E., "Fatwa," Encyclopaedia of Islam, New Edition, Vol. 1, Leiden: E.J. Brill, 1991, p. 866.

Wildan, Muhammad, "Radical Islamism in Solo: A Quest of Muslim's Identity in a Town of Central Java Indonesia", PhD Dissertation, Institute of Islamic World and Civilization, Universiti Kebangsaan Malaysia, Bangi, 2009, chapter 3.

Witkam, J.J., "Fatwa's over de Fonografie van de Koran," ZemZem, No. 2, 2007, pp. 82-95, 139-140.

Zuhri, Syaifudin, "Majlis Tafsir al-Qur'an and its Struggle for Islamic Reformism" in Kees van Dijk and Jajat Burhanuddin (eds.), Islam in Indonesia: Contrasting Images and Interpretations, Amsterdam: Amsterdam University Press, forthcoming 2013.

----, "Gerakan Purifikasi di Jantung Jawa: Studi tentang Majlis Tafsir Al-Qur'an (MTA)," in Yudian Wahyudi (ed.), Gerakan Wababi di Indonesia: Dialog dan Kritik, Yogyakarta: Pesantren Nawesea Press, 2009, pp. 281-316. 